\title{
APLIKASI MOBILE SIMULASI PERHITUNGAN KREDIT PEMBELIAN SEPEDA MOTOR PADA PT TUNAS MOTOR PRATAMA
}

\author{
Syaiful Ahdan ${ }^{1)}$, Hanifah Sekar Latih ${ }^{2)}$, Suci Ramadona ${ }^{2)}$ \\ 1) Teknologi Informasi, Fakultas Teknik dan Ilmu Komputer, Universitas Teknokrat Indonesia \\ 2) Sistem Informasi, Fakultas Teknik dan Ilmu Komputer, Universitas Teknokrat Indonesia \\ Jl. H.ZA Pagaralam, No 9-11, Labuhanratu, Bandarlampung \\ 2) Teknik Elektro, Politeknik Caltex Riau \\ Jl. Umban Sari, No.1, Rumbai Pekanbaru, Riau \\ Email : syaifulahdan@teknokrat.ac.id ${ }^{1)}$, hanifa.sekarlatih@gmail.com ${ }^{2)}$,suci.ramadona@pcr.ac.id ${ }^{2)}$
}

\begin{abstract}
Abstrak
Pada perusahaan yang bergerak dalam bidang penjualan, proses pembelian merupakan suatu hal yang sangat penting dalam proses bisnis, proses pembelian dapat dilakukan secara tunai dan kredit, pembelian yang dilakukan dengan cara kredit adalah pembelian yang di bayar tunai pada waktu yang akan datang. PT Tunas Motor Pratama adalah salah satu perusahaan yang melayani penjualan motor secara kredit, dalam melakukan proses perhitungan seperti menghitung uang muka dan angsuran masih menggunakan cara konvensional yaitu dengan menggunakan kalkulator, sehingga dalam proses perhitungan dapat terjadi kesalahan dan membutuhkan waktu untuk melakukan perhitungan biaya kredit karena karyawan harus menghitung dan menulis kembali rincian biaya kredit di kertas untuk diberikan kepada konsumen.
\end{abstract}

Dalam penelitian ini penulis malakukan rancang bangun sistem mengatasi permasalahan tersebut yaitu berupa simulasi perhitungan uang muka dan kredit pembelian sepeda motor yang dapat memudahkan pelayanan bagi kepada pelanggan dalam proses perhitungan uang muka kredit. Perancangan aplikasi ini menggunakan metode waterfall, Untuk metode aliran data menggunakan usecase diagram, activity diagram, class diagram dan sequence diagram. Aplikasi simulasi perhitungan uang muka kredit dibangun dengan menggunakan platform berbasis android agar aplikasi dapat dijalankan dengan menggunakan perangkat mobile dan dapat membantu kegiatan operasional perusahaan, sehingga dalam proses perhitungan uang muka dan kredit tidak menyita waktu karyawan, yang paling penting adalah dapat memberikan pelayanan yang baik bagi konsumen.

Kata kunci: Pemodelan, Rancang Bangun, Pembelian Kredit.

\section{PENDAHULUAN}

\section{A. Latar Belakang}

Suatu perusahaan, baik secara perseorangan, perseroan terbatas, maupun persekutuan komanditer, mempunyai tujuan yang sama dalam menjalankan aktivitasnya yaitu memaksimalkan laba yang merupakan syarat mutlak bagi kelangsungan hidup perusahaan. Salah satu caranya untuk mencapai laba yang maksimal adalah dengan meningkatkan penjualan produk usaha yang biasanya dilakukan oleh perusahaan dalam meningkatkan penjualannya adalah dengan menerapkan sistem penjualan kredit atau angsuran, dimana dengan adanya kebijakan dari perusahaan hal ini akan lebih memudahkan bagi pihak konsumen untuk memperoleh barang atau produk yang diinginkannya ( $\mathrm{H}$. Hasbudin Wa Ode Nur Hidayah, 2013).

Simulasi Memiliki Peran penting dalam pemodelan dan dalam menganalisis kegiatan, karena memungkinkan estimasi kuantitatif dan dapat mempengaruhi proses perancangan pada kinerja sistem (Mojca Indihar Stemberger, 2001). Simulasi merupakan alat yang berguna untuk menganalisis sistem yang rumit dimana kita tidak dapat menggunakan metode standar dalam riset operasional (Tomas Domonkos, 2010). Simulasi juga merupakan alat yang sangat baik jika dipahami dengan benar (S.J Mason, 2018), selain itu simulasi dapat diartikan sebagai meniru suatu sistem nyata yang kompleks dengan penuh dengan sifat probabilistik, tanpa harus mengalami keadaan yang sesungguhnya. Hal ini dapat dilakukan dengan membuat sebuah miniatur yang representative dan valid dengan tujuan sampling dan survey statistik pada sistem nyata, sehingga perilaku sistem dapat diprediksi untuk dipelajari (Shannon 1976), (M. Lusiani, 2016).

Masyarakat saat ini membutuhkan teknologi yang dapat membantu mengatasi masalah-masalah yang dihadapi dalam kehidupan sehari-hari. Seperti halnya ponsel Android yang ikut mengembangkan aplikasi Smartphone Android. Pengkreditan semakin hari semakin berkembang dan semakin dibutuhkan masyarakat, masyarakat umumnya lebih memilih melakukan pembelian barang secara kredit dari pada membayar tunai (Djamaludin, 2009).

Beberapa keuntungan yang bisa diperoleh dengan penerapan sistem angsuran kredit, selain dapat menghemat waktu, biaya, juga efektifitas para customer atau calon pembeli. (Aria Budi Swasono dan Yahdi Kusnadi 2017). Aplikasi sistem simulasi kredit dapat memberikan informasi kepada konsumen tentang produk yang dipasarkan dan sistem pembayaran. (Dadi Rosadi, Purnomo 2012). Selain itu hasil perhitungan yang dihasilkan dapat dijadikan sebagai rekomendasi yang dapat digunakan pengguna aplikasi untuk menentukan 
pilihan sepeda motor yang tepat untuk diproses dalam pembelian kredit. (Maulana Pratikto, 2016).

Berdasarkan kesimpulan dari hasil penelitian yang dilakukan oleh (Isnaini Irawati 2015) bahwa penjualan kredit yang dilakukan secara komputerisasi akan lebih akurat serta tepat waktu dalam penyajian informasi yang dibutuhikan untuk pihak pemilik ataupun pelanggan.

PT Tunas Motor Pratama yang berada di jalan Ikan Tenggiri No 49 Teluk Betung Bandar Lampung merupakan dealer honda motor resmi yang berafiliasi dengan jaringan dealer dari Astra Honda. Dealer ini merupakan bengkel resmi Astra Honda Authorized Service Station (AHASS) yang melayani servis motor. Selain itu, dealer ini melayani penjualan motor secara tunai maupun kredit yang menjual berbagai produkproduk andalan dari PT Tunas Motor Pratama khususnya sepeda motor, dalam melakukan proses perhitungan seperti menghitung uang muka dan angsuran masih menggunakan cara konvensional yaitu dengan menggunakan kalkulator, sehingga dalam proses perhitungan dapat terjadi kesalahan dan membutuhkan waktu untuk melakukan perhitungan biaya kredit karena karyawan harus menghitung dan menulis kembali rincian biaya kredit di kertas untuk diberikan kepada konsumen.

\section{B. Rumusan Masalah}

Berdasarkan permasalahan yang telah di deskripsikan sebelumnya, maka perlu dibuatkan aplikasi simulasi perhitungan uang muka kredit pembelian sepeda motor agar dapat membantu mengurangi permasalahan tersebut, maka penulis tertarik untuk membahas lebih lanjut mengenai simulasi uang muka dan pembelian secara kredit dengan cara membuat rancangan dan membangun aplikasi mobile dengan menggunakan platform android. Dalam penelitian ini penulis membuat beberapa rumusan permasalahan yaitu :

1. Bagaimana membuat suatu sistem yang dapat membantu kegiatan operasional pada PT Tunas Motor Pratama agar tidak menyita waktu kinerja karyawan serta memberikan pelayanan yang baik bagi konsumen.

2. Bagaimana merancang dan membangun aplikasi simulasi perhitungan uang muka dan pembelian kredit sepeda motor berbasis android.

3. Mengetahui bagaimana cara perhitungan uang muka kredit sepeda motor pada PT Tunas Motor Pratama.

Ruang lingkup masalah untuk perhitungan uang muka kredit pembelian sepeda motor ini cukup luas, sehingga untuk menghindari penyimpangan tujuan, maka diperlukan sejumlah batasan masalah, yaitu : (1) Aplikasi ini untuk input minimum uang muka sebesar Rp. 1.950.000. (2) Simulasi perhitungan uang muka kredit hanya sampai 3 tahun (36 bulan). (3) Mengitegrasikan konsep perhitungan uang muka kredit dengan ketentutuan yang ada di perusahaan menjadi sebuah aplikasi android (4) Aplikasi yang dibangun hanya dapat berjalan pada telepon seluler yang berjalan pada sistem operasi android minimal 4.1 (ICS: Jelly Bean).

\section{Tujuan Penelitian}

Selain itu Tujuan dari penelitian ini adalah: (1) bagaimana mempermudah perhitungan kredit seperti menghitung angsuran, bunga, total uang muka dengan cepat, akurat dan mempermudah perhitungan uang muka kredit. (2) Membuat aplikasi perhitungan uang muka kredit berbasis Android. (3) Memberikan informasi lengkap kepada konsumen tentang rincian perhitungan pembelian kredit sepeda motor. (4) Memberikan analisa mengenai batas maksimal kredit yang dapat diajukan.

\section{Metodologi Penelitian}

\section{Kerangka Penelitian}

Berdasarkan kerangka penelitian yang ada, maka kerangka penelitian yang digunakan terdiri dari beberapa tahapan yaitu : (1) Problem, (2) Identification, (3) Proposed, (4) Validation, (5) Result. Adapun penjelasan dari kerangka penelitian dapat dilihat pada Gambar 1.1

\section{Problem}

- Perhitungan Uang Muka \& Angsuran > menggunakan Kalkulator - Akibatnya sering terjadi kesalahan (Perhitungan Angsuran)

- Membutuhkan waktu untuk menghitung rincian kredit

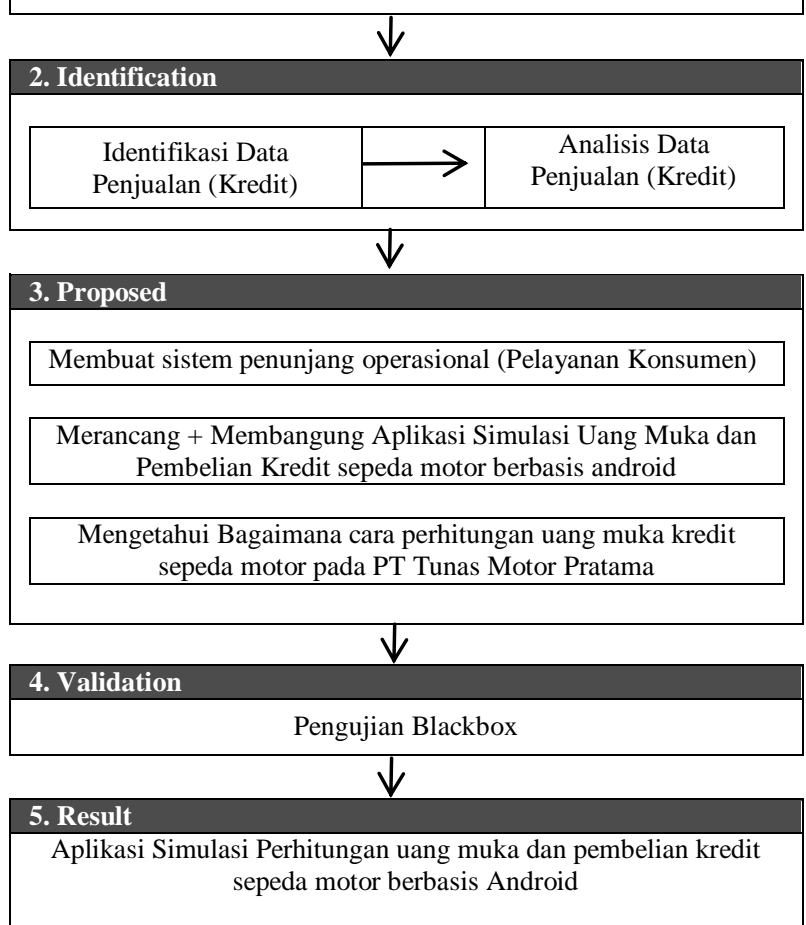

Gambar 1.1 Kerangka Penelitian, Sumber : Jeffrey, Whitten (2004)

\section{Tahapan Penelitian}

Berdasarkan tahapan penelitian yang ada, maka tahapan penelitian yang digunakan terdiri dari beberapa langkah yaitu: (1) Problem Identification, (2) Intervention, (3) Evaluation, (4) Reflection and Learning. Adapun penjelasan dari tahapan penelitian dapat dilihat Pada Gambar 1.2 

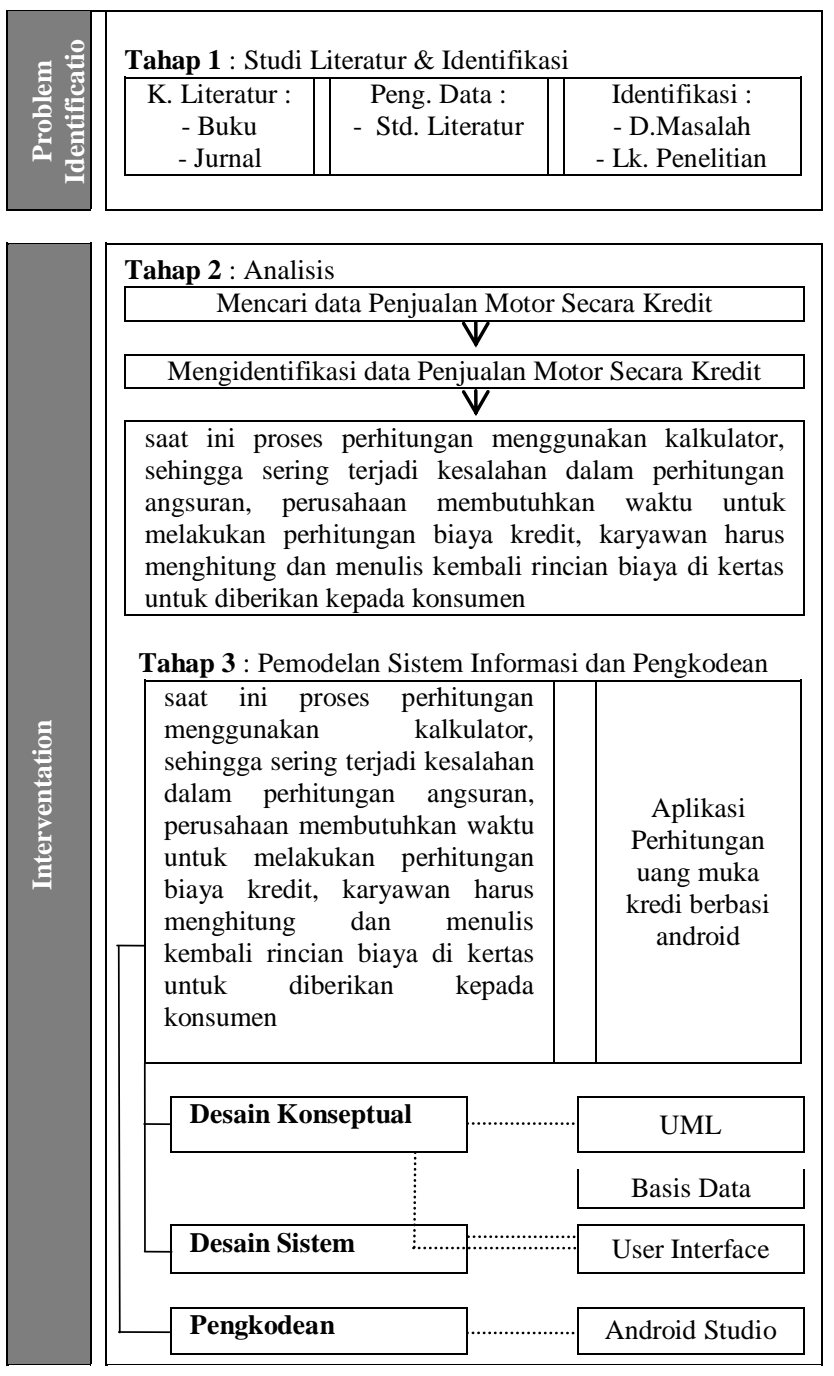

Tahap 4 : Validasi

Tahap Pengujian menggunakan Blackbox

Tahap 5 : Penutup

Aplikasi Perhitungan uang muka Kredit berbasis android, yang dapat membantu memudahkan karyawan dan pelanggan dalam melakukan perhitungan uang muka kredit.

Saran

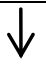

Untuk Penelitian selanjutnya, Aplikasi perhitungan uang muka ini dapat dikembangkan menjadi pengajuan uang muka Kredit

Gambar 1.2 Tahapan Penelitian, Sumber: Jeffrey, L Whitten (2004)

\section{Usulan Desain Pengembangan Sistem}

\section{(1) Usecase Diagram}

Usecase atau diagram usecase merupakan pemodelan untuk kegiatan pada sistem yang akan dibuat. Sistem memiliki 2 aktor yaitu admin dan pelanggan. Rancangan usecase diagram dapat dilihat pada gambar 1.3.

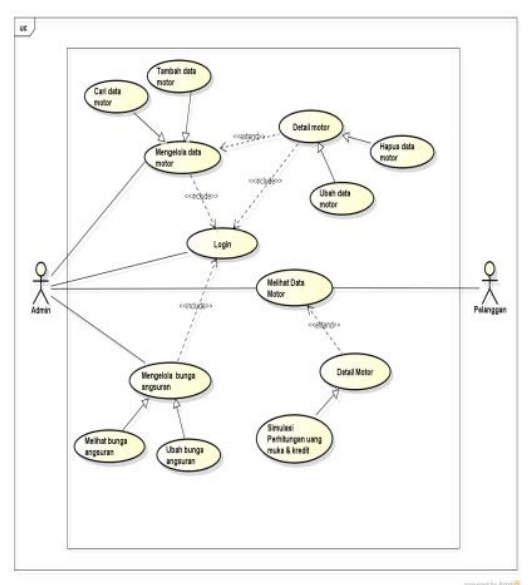

Gambar 1.3 Use Case Diagram

\section{Activity Diagram Pelanggan}

\section{(1) Activity Diagram Admin}

menggambarkan aliran kerja atau aktivitas dari sebuah sistem atau proses bisnis yang dilakukan oleh admin ke sistem, rancanganya dapat dilihat pada gambar 1.4 sebagai berikut:

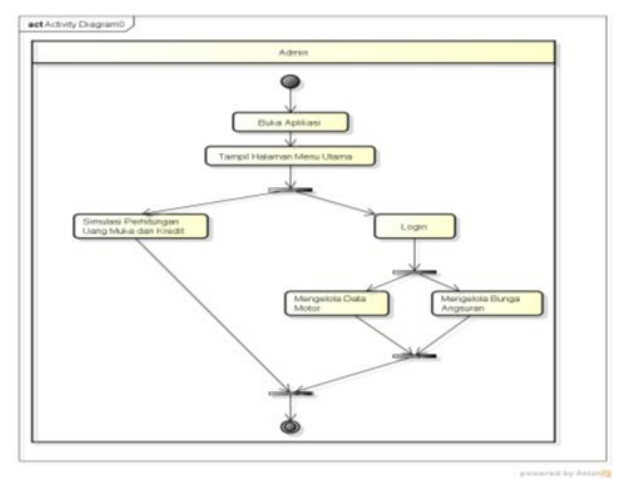

Gambar 1.4 Activity Diagram Admin

\section{(2) Activity Diagram Pelanggan}

Activity diagram pelanggan menggambarkan aliran kerja atau aktivitas dari sebuah sistem atau proses bisnis yang dilakukan oleh pelanggan ke sistem, untuk rancanganya dapat dilihat pada gambar 1.5.

\section{Class Diagram}

Class diagram adalah diagram yang menggambarkan struktur sistem dari segi pendefinisian kelas-kelas yang akan dibuat untuk membangun sistem. Kelas memiliki 3 bagian utama yaitu attribute, operation, dan name. Kelas-kelas yang ada pada struktur sistem harus dapat melakukan fungsi-fungsi sesuai dengan kebutuhan sistem. Untuk rancanganya dapat dilihat pada gambar 1.6 . 


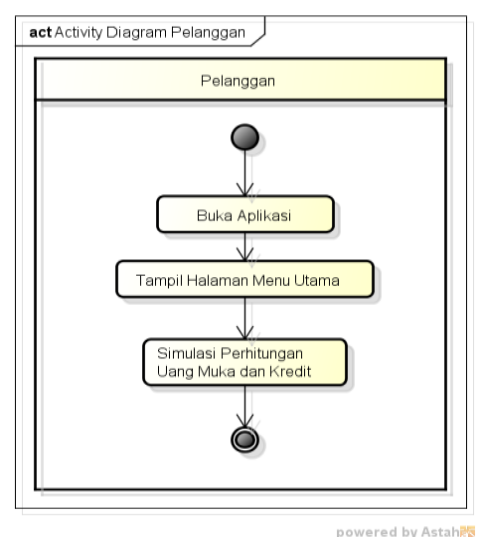

Gambar 1.5 Activity Diagram Admin

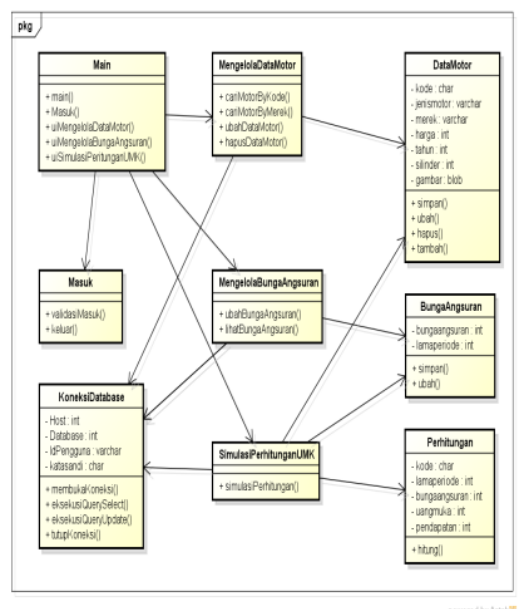

Gambar 1.6 Class Diagram

\section{PEMBAHASAN}

\section{A. Implementasi}

Sistem yang telah dibangun selanjutnya akan digunakan oleh administrator atau pegawai PT Tunas Motor Pratama dan pelanggan yang ingin melakukan simulasi perhitungan uang muka dan kredit motor pada PT Tunas Motor Pratama. Berikut penjelasan dari sistem pengguna (pelanggan dan admin) yang telah siap digunakan:

\section{Halaman Utama}

Pada menu halaman utama akan menampilkan seluruh data motor yang tersedia di PT Tunas Motor Pratama yang terdiri dari jenis motor matic, bebek, dan sport.

\section{Halaman Deskripsi}

Pada halaman Deskripsi Motor, akan ditampilkan deskripsi dari data motor yang dipilih. Pelanggan dapat memilih jenis motor berdasarkan penjelasan yang dapat dilihat secara lengkap pada halaman deskripsi motor.

\section{Halaman Simulasi}

Pada halaman simulasi pengguna dapat melakukan perhitungan uang muka sesuai dengan uang muka dan periode yang diinginkan. Pengguna juga diharuskan mengisi gaji pokok atau pendapatan per bulannya, agar hasil yang diperoleh sesuai dengan pendapatan pembeli.

perhitungan untuk mengetahui seberapa besar bunga dan angsuran perbulan diperoleh berdasarkan rumus perhitungan yang diterapkan pada PT Tunas Motor Pratama. Adapun rumus perhitungannya adalah sebagai berikut:

Angsuran perbulan $=(($ Harga Cash $-\mathrm{DP})+($ Harga Cash/Bunga))/Lama Angsuran

Contoh perhitungan untuk kasus simulasi perhitungan ini adalah sebagai berikut :

\begin{tabular}{|lll|}
\hline Harga Cash & $:$ & Rp 41.536.000,00.- \\
Periode Angsuran & $:$ & 36 Bulan \\
Uang Muka & $:$ & Rp 4.500.000,00.- \\
Bunga & $:$ & $1,24559505409583 \%$ \\
\hline
\end{tabular}

Penyelesaian : Angsuran/Bulan

$=((\operatorname{Rp} 41.536 .000,00-\mathrm{Rp} 4.500 .000,00)$

$+(\operatorname{Rp} 41.536 .000,00 / 1,24559505409583)) / 36$

= Rp 1.955.000,00 (dibulatkan)

berdasarkan uang muka dan periode yang diajukan oleh calon pembeli, maka akan diperoleh besarnya jumlah angsuran perbulannya adalah $\mathrm{Rp} 1.955 .000,00$.

\section{Halaman Hasil Simulasi}

Pada halaman hasil simulasi pengguna dapat melihat jumlah angsuran sesuai dengan uang muka dan periode yang inputkan sebelumnya oleh pengguna. Selain itu, pengguna juga mendapatkan informasi apakah dengan jumlah uang muka, periode angsuran, dan gaji tersebut pengguna secara sah dapat mengajukan kredit atau tidak. Halaman hasil simulasi perhitungan dapat dilihat seperti pada gambar 2.1

\section{Halaman Tambah Data Motor}

Halaman tambah motor berfungsi untuk melakukan menambahkan jenis motor baru. Jika dimasa yang akan datang terdapat stok motor dengan merk dan harga yang baru, maka admin dapat menambah data motor.

\section{Halaman Ubah Data Motor}

Halaman ubah data motor berfungsi untuk merubah data motor yang telah di inputkan apabila pada saat proses input data motor terjadi kesalahan maka admin dapat merubahnya.

\section{Halaman Kelola Bunga Angsuran}

Pada halaman kelola bunga angsuran, sistem akan menampilkan data bunga yang berlaku saat ini. Pada halaman ini admin dapat mengubah data bunga apabila terjadi perubahan besarnya bunga dengan cara menekan 
tombol ubah. Adapun tampilan dari halaman kelola bunga angsuran dapat dilihat pada gambar 2.3.

\section{Halaman Ubah Bunga Angsuran}

Pada halaman ubah bunga angsuran, admin dapat mengubah jumlah bunga berdasarkan periode serta berdasarkan ketentuan perusahaan. Adapun tampilan dari halaman ubah data bunga dapat dilihat pada gambar 2.4.

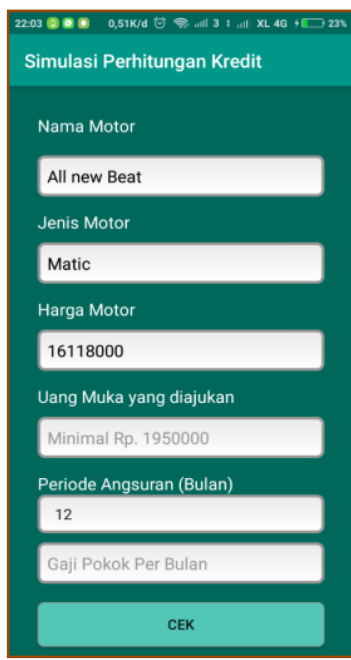

Gambar 2.1 Simulasi

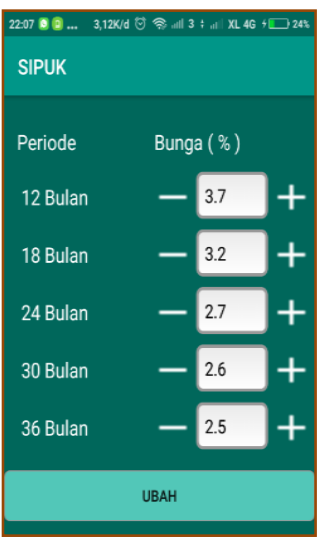

Gambar 2.3 Kelola Bunga

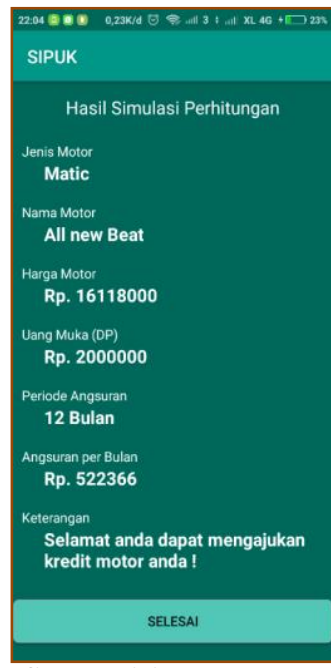

Gambar 2.2 Hasil simulasi

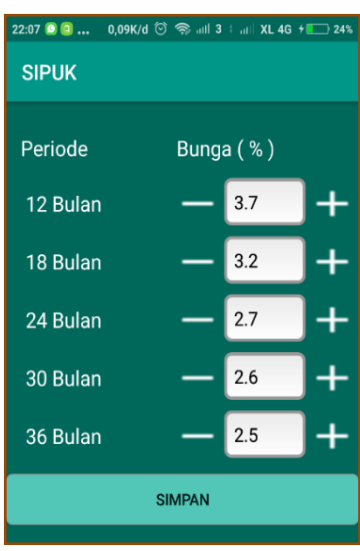

Gambar 2.4 Ubah Bunga

\section{KESIMPULAN}

Berdasarkan hasil penelitian mengenai aplikasi simulasi perhitungan uang muka dan kredit pembelian pada PT Tunas Motor Pratama, maka dapat diambil beberapa kesimpulan sebagai berikut.

1. Aplikasi simulasi dibangun dengan bahasa permograman IDE Java dengan software Android Studio sehingga menghasilkan suatu aplikasi android yang dapat membantu kegiatan operasional pada PT Tunas Motor Pratama sehingga tidak menyita waktu kinerja karyawan serta memberikan pelayanan yang baik bagi konsumen.

2. Aplikasi simulasi dirancang dan dibangun dengan beberapa tahapan, dimulai dari melakukan studi literatur dan identifikasi, dilanjutkan dengan melakukan analisis. Kemudian dari hasil analisis tersebut dilakukan tahapan pemodelan sistem informasi dan pengkodean (coding) dengan menggunakan software android studio, kemudian dilakukan validasi dengan dilakukan pengujian blackbox. Setelah aplikasi ini dinyatakan layak maka aplikasi dapat di implementasikan.

3. Proses perhitungan pada aplikasi simulasi menggunakan rumus yang telah diterapkan di perusahaan. Sehingga hasil yang diperoleh sudah sesuai dengan aturan aturan penjualan yang sudah ditetapkan.

\section{DAFTAR PUSTAKA}

NUR, HASBUDIN. Pengaruh uang Muka Dan Lama Angsuran Terhadap Volume Penjualan Motor Yamaha Pada CV Citra Selaras Raha. Jurnal Akuntansi dan Keuangan Fakultas Ekonomi dan Bisnis, UHO. 2013

VESNA BOSILJ VUKSIC, MOJCA INDIHAR STEMBERGER, JURIJ JAKLIC. Simulation Modelling Towards E-Business Models Development. International Journal of Simulation System, Science \& Technology. Vol.2 No.2. December 2001.

DOMONKOS, TOMAS. Computer simulation as a Toll for Analyzing and Optimizing Real-Life Process. Management Information Systems.Vol.5,1/2010, pp.013-018.

INGALLS, RICKI G. Introduction To Simulation. Proceeding of the 208 Winter Simulation Confe rence. IEEE 2018

LUASIANI, M., ADIPUTRA IRAWAN, R. Analisis Sistem Antrian Pada Bengkel Mobil Menggunakan Simulasi, JIEMS Journal of Industrial Engineering \& Managemen System. Vol.9, No.2, August 2016.

SWASONO, AB., KUSNADI, Y. Implementasi Sistem Informasi Angsuran Kredit Mobil (Studi Kasus PT Asrindo Jaya Jakarta), Jurnal Techno Nusa Mandiri Vol.XIV, No.1, Maret 2017.

ROSADI, D., PURNOMO. Simulasi Kredit Pemasaran Mobil Bekas Berbasis Web Menggunakan Code igniter Framework. Jurnal Computech \& Bisnis, Vol.6, No. 1, Juni 2012.

PRATIKTO, M., SURAYA., SUTANTA, E. Sistem Pembayaran Kredit Sepeda Motor Berbasis Mobile Menggunakan Android Studi Kasus di Dealer Honda Tunas Jaya Batas Kota Yogyakarta. Jurnal SCRIPT Vol.3 No.2, Juni 2016

IRAWATI, S., ANDRI, R. Komputerisasi Penjualan Sepeda Motor Secara Kredit Pada Dealer Endra Motor Sunggingan Boyolali. Jurnal IT CIDA Vol 1 No.1, Desember 2015. 